\title{
WAWASAN MENGENAI SISTEM PERINGATAN DINI KEKERINGAN DI INDONESIA
}

\section{INSIGHT TOWARDS DROUGHT EARLY WARNING SYSTEM IN INDONESIA}

\author{
Samuel Jonson Sutanto' \\ ${ }^{1)}$ Balai Sabo, Puslitbang Sumber Daya Air, Kementerian Pekerjaan Umum dan Perumahan Rakyat, Jl. Sopalan \\ Maguwoharjo, Depok Sleman, Yogyakarta 55282, Indonesia. \\ ${ }^{*}$ Sekarang berada di Hydrology and Quantitative Water Management, Environmental Sciences Group, \\ Wageningen University and Research, Droevendaalsesteeg 3a, 6708 WB, Wageningen, the Netherlands. \\ Corresponding email: congexs@yahoo.com
}

\begin{abstract}
ABSTRAK
Kekeringan merupakan salah satu bencana alam yang seringkali kurang diperhatikan karena sifat dari bencana itu sendiri yang terjadi secara perlahan. Namun jika dibandingkan dari kerugian yang dialami, terutama oleh petani, maka bencana kekeringan ini merupakan bencana yang tidak kalah pentingnya dibandingkan dengan bencana lainnya. Untuk mengurangi dampak yang diakibatkan dari bencana kekeringan ini, maka diperlukan suatu sistem yang dapat memberikan peringatan dini kekeringan beberapa bulan ke depan. Oleh karena itu, makalah ini membahas mengenai wawasan dalam pembuatan sistem peringatan dini kekeringan di Indonesia. Hasil analisis menunjukkan bahwa analisis kekeringan untuk menghitung tingkat kekeringan di masa yang akan datang dapat dibagi menjadi dua buah algoritma. Algoritma pertama digunakan untuk menghitung parameter-parameter distribusi atau nilai CDF (Cummulative Distribution Frequency) dari data historis untuk setiap bulannya dan setiap grid selnya. Algoritma kedua digunakan untuk menghitung nilai indek kekeringan dari data peramalan. Hasil dari peramalan kekeringan harus dapat menampilkan dua buah data, yaitu peta daerah yang akan mengalami kekeringan, dan grafik indek kekeringan untuk setiap provinsi di Indonesia dengan menampilkan batas atas dan bawah dari model. Jika data peramalan masa lampau (hindcast) dimiliki, maka koreksi bias terhadap data peramalan harus dilakukan untuk mendapatkan hasil peramalan yang lebih akurat. Dengan adanya pembahasan mengenai wawasan sistem peringatan dini kekeringan ini, maka diharapkan kedepannya Indonesia akan mempunyai sistem peringatan dini kekeringan.
\end{abstract}

Kata kunci: Kekeringan, sistem peringatan dini, algoritma-algoritma, koreksi bias

\begin{abstract}
Drought is often categorized as a natural disaster, which receives less attention compared to flood, earthquake, and landslide due to its slow development characteristic. However, the loss due to drought events especially for farmers is comparable with other hazards. To reduce the impact of droughts, a drought early warning system with a lead time of several months ahead is needed. This paper, therefore, exploits the insight of drought early warning system that can be developed in Indonesia. Results show that drought analysis to calculate the forecasted drought severity can be separated into two algorithms. First algorithm is developed to calculate the distribution parameters or CDF values for each month and in each grid cell using historical data that will be used in second algorithm. The second algorithm is built to calculate the drought severity index using forecast data and distribution parameters or CDF values. Outcomes of the analysis are forecasted drought regions and drought index in each province in Indonesia, showing the top and bottom boundaries of the forecast essembled models. Bias correction must be carried out if the hindcast data are available in order to obtain more accurate drought forecasting results. The insight of drought early warning system that is described in this paper hopefully can guide the researchers to develop the drought early warning system in Indonesia.
\end{abstract}

Keywords: Droughts, early warning system, algorithms, bias correction 


\section{PENDAHULUAN}

Kekeringan merupakan salah satu bencana alam yang sering kali kurang mendapatkan perhatian meskipun memiliki dampak yang serius terhadap ketahanan pangan, kebakaran hutan, atau bahkan menyebabkan kematian. Dibandingkan dengan bencana alam lain seperti banjir, tanah longsor, dan gunung meletus, bencana kekeringan mempunyai ciri kas yang berbeda. Bencanabencana tersebut diatas biasanya terjadi secara mendadak dan dalam waktu yang relatif singkat, sedangkan kekeringan merupakan bencana alam yang sering disebut sebagai bencana yang merangkak (creeping disaster). Hal ini dikarenakan pembentukan bencana alam ini cenderung perlahan, mempunyai konsekuensi yang tidak langsung, sering kali tidak terdeteksi, dan dapat terjadi dalam jangka waktu lama dari bulanan hingga tahunan (Dai, 2010; van Loon, 2015).

Benjamin Franklin (1706-1790) salah satu bapak pendiri negara Amerika berkata: "When the well's dry, we know the worth of water" Hal ini menjadi nyata ketika bencana kekeringan sudah terjadi. Kita baru sadar akan adanya bencana tersebut ketika lahan pertanian kita kering, sumursumur menjadi dangkal, air sungai surut, dan tinggi muka air di bendungan-bendungan menjadi sangat rendah. Kerugian yang ditimbulkan oleh bencana ini juga tidak kecil. Di Amerika misalnya, kerugian yang ditimbulkan oleh kekeringan adalah sebesar 6-8 milyar USD rata-rata setiap tahunnya (FEMA, 1995). Kekeringan yang pernah terjadi di Afrika pada tahun 1980 menyebabkan lebih dari 500 ribu orang meninggal dunia (Kallis, 2008). Di Eropa, kekeringan terparah terjadi pada tahun 2003 dan menimbulkan kerugian yang tidak sedikit, baik dari segi material maupun korban jiwa. Setidaknya tercatat $70 \mathrm{ribu}$ orang meninggal sebagai akibat dari kekeringan dan aliran panas (Robine, dkk., 2008), dengan kerugian material sebesar 11,6 milyar euro (EurAqua, 2004).

Di Indonesia sering kali kekeringan parah terjadi sebagai dampak dari El Niño-Southern Oscillation (ENSO; Sutanto, dkk., 2013), yang terjadi sebagai dampak dari perubahan suhu muka air laut (Sea Surface Temperature, SST) di laut Pasifik. Pengaruh dari ENSO di Indonesia adalah curah hujan yang lebih tinggi dari normal (La Niña) dan curah hujan dibawah normal (El Niño) (JunIchi, dkk., 2002). Kekeringan yang terjadi pada tahun 2015 lalu menyebabkan 8 provinsi di Indonesia mengalami krisis air bersih dan air minum, dan tercatat lebih dari 20 ribu hektar lahan padi di Jawa Timur mengalami kekeringan (CNN Indonesia, 2015). Dampak kekeringan yang diberitakan diatas belum termasuk wilayah lainnya yang mengalami gagal panen dan kebakaran hutan sebagai akibat dari kekeringan (Taufik, dkk., 2017).

Untuk mengurangi kerugian yang terjadi akibat dari bencana kekeringan, maka diperlukan adanya sistem peringatan dini bencana kekeringan di Indonesia. Dengan adanya sistem peringatan dini ini, Pemerintah dapat menampung lebih banyak air di bendungan-bendungan yang berfungsi sebagai suplai irigasi dan air baku untuk digunakan pada saat kekeringan terjadi. Dilain pihak, petani bisa menyesuaikan jenis tanaman yang akan ditanam. Di bidang pertanian, teknologi satelit yang ada dewasa ini sangat berguna untuk memetakan luasan lahan pertanian yang terdampak kekeringan (lihat www.g4indo.org). Oleh Kementerian pertanian, sistem ini telah di uji cobakan pada beberapa Kabupaten di Indonesia dengan menggunakan indeks kekeringan. Dengan adanya teknologi ini dan sistem peringatan dini kekeringan di Indonesia, maka diharapkan dampak kekeringan yang terjadi di Indonesia dapat diminimalkan.

Makalah ini akan membahas mengenai wawasan atau pandangan mengenai sistem peringatan dini kekeringan yang dapat diterapkan di Indonesia. Bagian pertama membahas mengenai latar belakang perlunya studi ini, bagian kedua membahas mengenai metode yang lazim digunakan untuk mengidentifikasi kekeringan, bagian ketiga membahas mengenai cara-cara aplikasi sistem peringatan dini kekeringan dan apa saja yang harus ditampilkan dalam sistem peringatan dini tersebut. Bagian ke empat yang merupakan seksi terakhir membahas kesimpulan dan saran-saran yang dirasa perlu dilakukan.

\section{METODOLOGI}

\section{Indeks Kekeringan pada Umumnya}

Banyak metode dan indeks klimatologi yang telah digunakan untuk mengukur tingkat kekeringan. Indeks yang menjadi acuan untuk mengukur kekeringan di Amerika oleh pemerintah adalah Palmer Drought Severity Index (PDSI; Palmer, 1965; Alley, 1984), yang kemudian disempurnakan oleh Wells, dkk (2004) dengan metode yang bernama Self-Calibrating PDSI (SCPDSI). Namun metode yang paling banyak digunakan di Indonesia adalah Standardized Precipitation Index (SPI; McKee, dkk., 1993) dan Standardized Precipitation Evaporation Index (SPEI; Vicente-Serrano, dkk., 2010). Kedua indeks kekeringan tersebut (SPI dan SPEI) banyak digunakan karena relatif mudah dan hanya 
memerlukan data hujan (SPI) dan data hujantemperature (SPEI). Salah satu kekurangan dari metode-metode tersebut adalah panjang data yang diperlukan untuk menghitung nilai Cumulative Distribution Frequency (CDF) yaitu minimal 30 tahun (McKee, dkk., 1993; Wu, dkk., 2005). Metode lainnya adalah Standardized Groundwater Index (SGI; Bloomfield dan Marchant, 2013) dan Standardized Runoff Index (SRI; Shukla dan Wood, 2008; Hatmoko, dkk., 2015).

Selain metode standarisasi yang telah disebutkan di atas, ada metode lain yang dapat digunakan untuk menganalisis kekeringan. Metode tersebut dinamakan metode nilai batas (threshold level method; Yevjevich, 1967; Hisdal, dkk., 2004). Pada metode ini, kekeringan terjadi jika nilai parameter-parameter yang akan diukur (misal: hujan, debit, air tanah, aliran permukaan) mempunyai nilai dibawah batas ambang. Nilai batas ambang tersebut bisa merupakan nilai $80^{\text {th }}$ persentil dari kurva durasi bulanan maupun 90th persentil $\left(Q_{80}\right.$ atau $\left.Q_{90}\right)$. Nilai batas yang biasa digunakan dalam analisis kekeringan adalah $\mathrm{Q}_{80}$ (van Loon dan van Lanen, 2012). Pada studi ini hanya akan dibahas dua metode standarisasi yang banyak digunakan di Indonesia dan dapat diaplikasikan dalam sistem peringatan dini kekeringan di Indonesia, yaitu SPI dan SPEI. Selain sudah digunakan secara luas di Indonesia, data yang digunakan pada kedua metode tersebut, yaitu hujan dan suhu udara, relatif lebih mudah di dapatkan di Indonesia. Data hujan dan suhu udara bisa di dapatkan dari data re-analisis seperti ERAInterim (Betts dan Jakob, 2002), maupun dari satelit TRMM (Schumacher dan Houze, 2003). Data hujan dari satelit TRMM sudah tersimpan dengan baik dalam program Delft-FEWS yang dimiliki oleh Puslitbang Air.

\section{Indeks Kekeringan SPI}

Indeks kekeringan SPI ini pada prinsipnya adalah menghitung nilai dari parameter distribusi gamma untuk setiap bulannya, yang kemudian di konversikan ke standard distribusi normal untuk didapatkan nilai SPInya. Fungsi dari distribusi peluang terjadinya kekeringan dengan menggunakan fungsi distribusi gamma dijabarkan sebagai berikut (untuk hujan lebih besar dari 0):

$g(x)=\frac{1}{\beta^{\alpha} \Gamma(\alpha)} x^{\alpha-1} e^{-x / \beta}$

$x$ adalah jumlah hujan bulanan, $\alpha$ dan $\beta$ adalah parameter-parameter bentuk dan skala. $\Gamma(\alpha)$ adalah fungsi sebaran gamma.

Parameter-parameter bentuk dan skala dapat dihitung dengan metode maksimum kesamaan untuk setiap stasiun sebagai berikut: $\alpha=\frac{1}{4 A}\left(1+\sqrt{1+\frac{4 A}{3}}\right)$

$\beta=\frac{\bar{x}}{\alpha}$

dengan

$A=\ln (\bar{x})-\frac{\sum \ln (x)}{n}$

$n$ adalah jumlah data pengamatan, $x$ adalah ratarata jumlah hujan setiap bulannya.

Parameter-parameter yang dihasilkan kemudian digunakan untuk menghitung besarnya distribusi peluang akumulasi pada kejadian hujan tertentu yang dirubah menjadi fungsi gamma yang tidak lengkap:

$G(x)=\int_{0}^{x} g(x) d x=\frac{1}{\beta^{\alpha} \Gamma(\alpha)} \int_{0}^{x} x^{\alpha-1} e^{-x / \beta}$

Fungsi distribusi gamma tidak dapat didefinisikan untuk jumlah hujan sama dengan nol dan ada kemungkinan jumlah hujan yang terjadi sama dengan nol. Oleh karena itu distribusi peluang akumulasi harus dimodifikasi supaya dapat digunakan jika didapati tidak ada kejadian hujan pada data pengamatan:

$H(x)=q+(1-q) G(x)$

$H(x)$ adalah distribusi peluang akumulasi yang telah dimodifikasi untuk kejadian dimana tidak terdapat hujan. Konstanta $q$ adalah kemungkinan tidak terjadinya hujan.

Setelah itu indek SPI dapat dihitung dengan mengubah jumlah distribusi peluang terjadinya kekeringan ke standar distribusi normal $(Z)$.

$Z=S P I=-\left(t-\frac{c_{0}+c_{1} t+c_{2} t^{2}}{1+d_{1} t+d_{2} t^{2}+d_{3} t^{3}}\right)$
$Z=S P I=+\left(t-\frac{c_{0}+c_{1} t+c_{2} t^{2}}{1+d_{1} t+d_{2} t^{2}+d_{3} t^{3}}\right)$

dengan

$\begin{aligned} t & =\sqrt{\ln \left(\frac{1}{(H(x))^{2}}\right)} \\ t & =\sqrt{\ln \left(\frac{1}{(1-H(x))^{2}}\right)}\end{aligned}$

Persamaan 7 dan 9 digunakan untuk $0<H(x) \leq 0,5$ dan persamaan 8 dan 10 digunakan untuk $0,5<H(x)<1 . \quad c_{0}=2,515517, \quad c_{1}=0,802853$, $c_{2}=0,010328, d_{1}=1,432788, d_{2}=0,189269, \quad$ dan $d_{3}=0,001308$.

\section{Indeks Kekeringan SPEI}

Indeks kekeringan SPEI merupakan indeks kekeringan yang berdasarkan dari perbedaan flux 
balance antara hujan dan evapo-transpirasi. Evapotranspirasi pada metode ini dapat dihitung dengan menggunakan metode Thornthwaite yang hanya membutuhkan data suhu udara, maupun dengan metode lainnya seperti Penman-Monteith, Blaney-Criddle, the Hargreaves, Priestley-Taylor, dll (Djaman, dkk., 2015). Kelebihan atau kekurangan air bulanan dari metode SPEI dihitung dari perbedaan jumlah curah hujan dan potensial evapo-transpirasi sebagai berikut:

$$
D_{i}=P_{i}-P E T_{i}
$$

Dimana $P_{i}$ adalah jumlah hujan pada bulan ke- $i$ dan $P E T_{i}$ adalah evapotranspirasi potensial pada bulan ke-I dalam milimeter. Diagram rasio Lmoment digunakan untuk menghitung perbedaan waktu distribusi. Diagram rasio L-moment dapat dihitung dengan menggunakan rumus sebagai berikut:

$$
\tau_{3}=\frac{\lambda_{3}}{\lambda_{2}}, \tau_{4}=\frac{\lambda_{4}}{\lambda_{2}}
$$

Dengan $\lambda_{2}, \lambda_{3}$, and $\lambda_{4}$ adalah L-moment dari data berurutan $D$ yang diperoleh dari probabilityweighted moments (PWMs, simbol $w$ ) dengan menggunakan rumus-rumus:

$$
\begin{aligned}
& \lambda_{1}=w_{0} \\
& \lambda_{2}=w_{0}-2 w_{1} \\
& \lambda_{3}=w_{0}-6 w_{1}+6 w_{2} \\
& \lambda_{4}=w_{0}-12 w_{1}+30 w_{2}-20 w_{3}
\end{aligned}
$$

PWMs, $\quad w$, dapat dihitung dengan menggunakan rumus:

$$
w_{s}=\frac{1}{N} \sum_{i=1}^{N}\left(1-F_{i}\right)^{s} D_{i}
$$

$s$ adalah nomer PWMs dan $F_{i}$ adalah analisis frekuensi yang dihitung dengan menggunakan pendekatan dari Hosking(1990).

$$
F_{i}=\frac{i-0.35}{N}
$$

$i$ adalah data pengamatan yang diurutkan dari kecil ke besar dan $N$ adalah jumlah data pengamatan. Probability density function dari distribusi loglogistic tiga parameter dihitung dengan rumus:

$f(x)=\frac{\beta}{\alpha}\left(\frac{x-\gamma}{\alpha}\right)^{\beta-1}\left[1+\left(\frac{x-\gamma}{\alpha}\right)^{\beta}\right]^{-2}$

Dengan $\alpha, \beta, \gamma$ adalah parameter-parameter ukuran, bentuk, dan asal untuk nilai $D$ dalam batas
$\gamma>D<\infty$ yang mengikuti prosedur L-moment sebagai berikut:

$$
\begin{aligned}
& \beta=\frac{2 w_{1}-w_{0}}{6 w_{1}-w_{0}-6 w_{2}} \\
& \alpha=\frac{\left(w_{0}-2 w_{1}\right) \beta}{\Gamma(1+1 / \beta) \Gamma(1-1 / \beta)} \\
& \gamma=w_{0}-\alpha \Gamma\left(\frac{1+1}{\beta}\right) \Gamma\left(\frac{1-1}{\beta}\right)
\end{aligned}
$$

Dengan $\Gamma(\beta)$ adalah fungsi gamma distribusi dari $\beta$.

Indeks kekeringan SPEI untuk musim basah dan kering dihitung dari nilai $F(x)$ yang di standardisasi sebagai berikut:

$$
\begin{aligned}
& F(x)=\left[1+\left(\frac{\alpha}{x-\gamma}\right)^{\beta}\right]^{-1} \\
& S P E I=W-\frac{c_{0}+c_{1} W+c_{2} W^{2}}{1+d_{1} W+d_{2} W^{2}+d_{3} W^{3}}
\end{aligned}
$$

Dengan

$$
W=\sqrt{-2 \ln (P)}
$$

$P$ adalah kemungkinan terlampauinya nilai $D$. Rumus 24 hanya berlaku untuk $P \leq 0,5$, and $P=1$ $F(x)$. Jika $P>0,5$, maka $P$ digantikan oleh $1-P$ dan tanda dari SPEI dibalik. Konstanta diatas sama halnya dengan konstanta SPI yaitu sebagai berikut: $c_{0}=2,515517, \quad c_{1}=0,802853, \quad c_{2}=0,010328$, $d_{1}=1,432788, \quad d_{2}=0,189269, \quad d_{3}=0,001308$. Klasifikasi kekeringan berdasarkan indeks SPI dan SPEI dapat dilihat pada Tabel 1.

\section{Data yang digunakan}

Dalam studi ini data hujan dan suhu udara yang digunakan berasal dari data ERA Interim ECMWF (Euroepean Center for Medium Weather Forecast). ERA Interim data merupakan data yang diperoleh dari hasil pemodelan yang dirancang dengan mengasimilasi data pengamatan, baik data pengamatan permukaan (stasiun klimatologi dan radar) maupun data dari satelit sebanyak kurang lebih $10^{7}$ data setiap harinya (Dee, dkk., 2011). ERA Interim data memiliki spasial resolusi sebesar $0,125^{\circ} \times 0,125^{\circ}$, atau kurang lebih seluas $11 \mathrm{~km} \times 11$ $\mathrm{km}$. Temporal resolusi yang dimiliki data tersebut adalah 3 jam-an dari tahun 1979 hingga 2017, namun dalam studi ini digunakan data dengan temporal resolusi bulanan mengingat analisis SPI dan SPEI hanya membutuhkan data hujan dan suhu udara bulanan. Batas wilayah Indonesia yang 
digunakan dalam studi ini adalah $7 \mathrm{~N}-12 \mathrm{~S}$ dan 90E142E.

Tabel 1 Klasifikasi kekeringan berdasarkan indek SPI dan SPEI.

\begin{tabular}{ccc}
\hline Indeks & Klasifikasi & $\begin{array}{c}\text { Peluang } \\
\text { terjadi }\end{array}$ \\
\hline$>2$ & Basah ekstrem & 2.3 \\
1.5 to 1.99 & Sangat basah & 4.4 \\
1 to 1.49 & Basah sedang & 9.2 \\
0 to 0.99 & Basah ringan & 34.1 \\
0 to -0.99 & Kering ringan & 34.1 \\
-1 to -1.49 & Kering sedang & 9.2 \\
-1.5 to -1.99 & Kering parah & 4.4 \\
$-2<$ & Kering ekstrem & 2.3 \\
\hline
\end{tabular}

Dalam studi ini hanya akan dibahas mengenai proses dan apa saja yang diperlukan untuk membangun sistem peringatan dini bencana kekeringan. Data yang digunakan adalah data lampau, sedangkan untuk data peramalan itu sendiri bisa digunakan data yang berasal dari ECMWF IFS (Integrated Forecast System), dimana data peramalan tersebut tersedia baik harian maupun hingga 7 bulan (Seasonal) (Hamill, dkk., 2007; Persson, 2001). Untuk Indonesia akan lebih baik jika data peramalan yang digunakan adalah data ECMWF yang berasal dari Badan Meteorologi dan Klimatologi Geofisika (BMKG). Data tersebut didapat dari kerjasama antara Puslitbang Air dan BMKG dan sudah di implementasikan ke dalam sistem peringatan dini banjir (Flood Early Warning System, FEWS; Werner, dkk., 2013).

\section{HASIL DAN PEMBAHASAN}

\section{Skema Sistem Peringatan Dini Kekeringan}

Untuk membangun suatu sistem peringatan dini bencana kekeringan, diperlukan suatu perangkat lunak yang bisa membaca data hasil peramalan dan kemudian mensimulasikan data tersebut dengan algoritma atau skrip dalam bahasa program yang sudah dibuat, dalam hal ini SPI dan SPEI algoritma. Untuk sistem peringatan dini yang digunakan disarankan untuk menggunakan sistem yang sudah dijalankan oleh Balai Litbang Hidrologi dan Tata Air untuk satgas banjir dan oleh Balai Litbang Sabo untuk peringatan bencana longsor, yaitu Delft-FEWS. Delft-FEWS disarankan untuk digunakan karena data hujan dari satelit TRMM dan data peramalan hujan BMKG sudah terintegrasi dengan baik dalam sistem tersebut. Skema keseluruhan dari sistem peringatan dini bencana kekeringan bisa dilihat pada Gambar 1 .

Sistem peringatan dini ini terdiri dari minimal sebuah komputer dengan kapasitas tampung data yang cukup besar (Tera Byte, TB). Komputer tersebut diperlukan untuk mengolah data peramalan dengan beberapa hasil pemodelan (essembles) dan menjalankan algoritma kekeringan dengan perhitungan SPI dan SPEI untuk setiap grid selnya. Untuk wilayah Indonesia dengan resolusi $0,125^{\circ} \times 0,125^{\circ}$, maka dihasilkan grid sel sebanyak 417x169 (longitude x latitude), dan data bulanan sebanyak 457 data (Januari 1979 hingga Januari 2017).

Salah satu hasil dari analisis peramalan kekeringan adalah peta daerah yang mungkin terdampak kekeringan setiap bulannya dalam 7 bulan kedepan. Dalam peta tersebut harus bisa terlihat tingkat kekeringan yang akan terjadi (rendah, sedang, tinggi, dan ekstrim). Selain peta, data grafik dari hasil analisis SPI dan SPEI juga harus dapat dilihat untuk setiap provinsi. Informasi kekeringan ini kemudian dapat disebarluaskan kepada badan penanggulangan bencana (misal Badan Penanggulangan Bencana Daerah, BPBD dan Badan Nasional Penanggulangan Bencana, BNPB), kepada masyarakat luas misal melalui website, dan kepada pemerintah setempat. Validasi dapat dilakukan jika bencana sudah/tidak terjadi kedepannya. Sub bab berikut akan membahas secara detail mengenai algoritma kekeringan untuk peringatan dini dan contoh-contoh hasil peramalan yang bisa ditampilkan. 


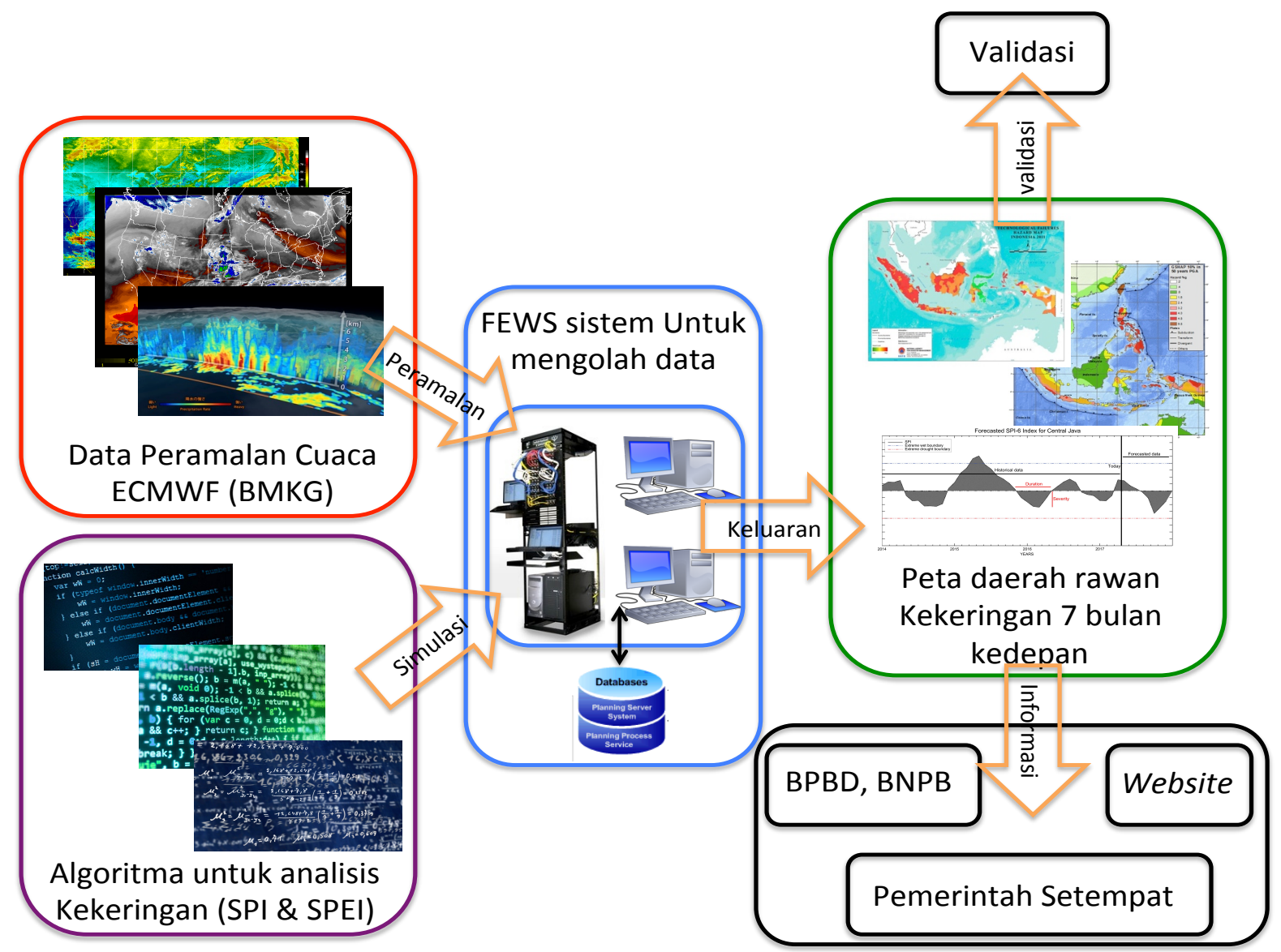

Gambar 1 Skema sistem peringatan dini kekeringan

\section{Algoritma untuk Analisis Kekeringan}

Hal terpenting dalam mengembangkan sistem peringatan dini kekeringan adalah adanya algoritma untuk mengolah data hasil peramalan (hujan dan suhu udara), dan kemudian menghitung indeks kekeringan yang akan terjadi dengan menggunakan data peramalan tersebut (SPI dan SPEI), yang dituangkan ke dalam algoritma bahasa program. Dalam kajian ini algoritma perhitungan kekeringan dibuat dengan menggunakan bahasa program IDL 8.4 (Interactive Data Language, Harris Geospatial). Bahasa program ini digunakan karena mempermudah perhitungan indeks kekeringan pada setiap grid sel (70.473 grid sel) dan kemudian menampilkan hasilnya.

Dikarenakan grid sel yang cukup banyak dan panjangnya data yang diperlukan, maka algoritma perhitungan kekeringan ini dapat dibagi menjadi dua bagian. Pada bagian pertama (warna kuning, Gambar 2) yang perlu dihitung terlebih dahulu adalah pembuatan basis data parameter-parameter yang diperlukan ( $\alpha$, dan $\beta$, rumus 2 dan 3 ) atau basis data yang berisikan nilai Cummulative Distribution Frequency (CDF, atau $G_{x}$ dalam rumus 5) untuk SPI. Untuk algoritma perhitungan SPEI, basis data yang perlu dihitung terlebih dahulu adalah parameter-parameter $\alpha, \beta$, dan $\gamma$ (rumus 2022 ) atau basis data yang berisikan nilai $f(x)$ pada rumus 19.

Bagian pertama ini dihitung terlebih dahulu menggunakan data historis dengan panjang data minimum 30 tahun. Perhitungan indeks kekeringan ini memakan waktu yang cukup lama karena data yang harus diolah untuk seluruh Indonesia cukup besar, namun cukup dilakukan sekali. Basis data tersebut baik untuk SPI dan SPEI disimpan ke dalam server yang setiap kali akan dibaca oleh sistem untuk menghitung indeks kekeringan dengan data peramalan. Algoritma bagian pertama tidak perlu disimpan (encapsulated) ke dalam sistem FEWS, hanya hasil perhitungannya saja yang perlu disimpan.

Algoritma bagian kedua ini (warna hijau Gambar 2) berisikan perhitungan data peramalan menjadi indeks kekeringan dengan menggunakan basis data yang sudah disiapkan sebelumnya (bagian satu). Alrotima bagian kedua ini berisikan rumus perhitungan indeks kekeringan SPI (rumus 6-10) dan SPEI (rumus 23-25). Dengan adanya pembagian perhitungan indek kekeringan menjadi 
2 bagian, maka perhitungan indek kekeringan dengan data peramalan menjadi singkat dan cepat, karena sistem hanya perlu merubah data peramalan menjadi indek kekeringan. Dengan adanya pembagian ini, maka setiap kali ada data peramalan terbaru, maka sistem tidak perlu menghitung semua rumus indek kekeringan dari awal. Contoh algoritma bagian pertama dapat dilihat pada Gambar 3. Kotak merah pada Gambar 3 menandakan bahwa nilai CDF hasil perhitungan di simpan menjadi basis data dengan nama CDF_SPI6_ECMWF_Indo_Full.sav, yang nantinya akan dipanggil kembali pada algoritma bagian kedua. Pada Gambar 3 juga dapat dilihat bahwa proses perhitungan CDF memakan waktu yang cukup lama karena perhitungan tersebut dilakukan untuk setiap grid sel, setiap bulan, dan selama lebih dari 30 tahun data.

Parameter-parameter perhitungan indek kekeringan dan basis data distribusinya baik SPI dan SPEI disimpan kedalam basis data untuk setiap grid selnya dan untuk setiap bulannya. Hal ini dikarenakan karakteristik data setiap bulannya berbeda antara bulan yang satu dengan yang lainnya. Dengan kata lain, setiap data berisikan informasi dengan dimensi 417×169×12 (longitude, latitude, bulan).

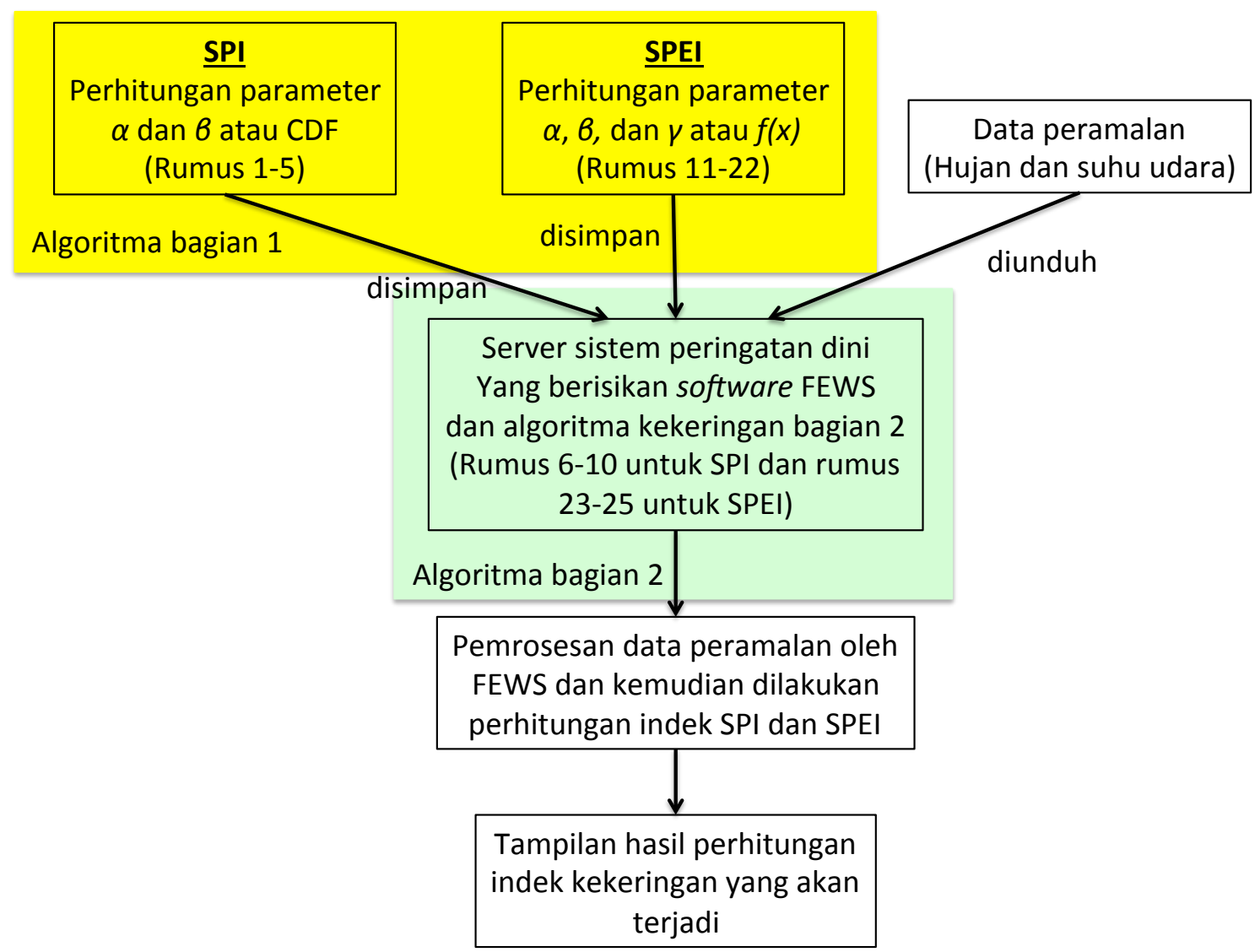

Sebagai contoh, jika bulan sekarang adalah bulan April, maka data peramalan akan berisikan data hujan dan suhu udara pada bulan Mei hingga Nopember ( 7 bulan dengan asumsi data peramalan adalah data ECMWF IFS SEAS). Dengan diketahuinya bahwa data peramalan adalah data pada bulan Mei hingga November, maka sistem FEWS akan menggunakan basis data hasil perhitungan algoritma bagian pertama hanya pada bulan-bulan tersebut. Kemudian data peramalan akan dikonversi menjadi indek kekeringan dengan menggunakan basis data pada bulan yang sama. Contoh proses penggunaan basis data CDF pada perhitungan SPI akan dibahas pada sub bab berikut.

\section{Perhitungan Nilai CDF Data Peramalan}

Pada sub bab sebelumnya disinggung mengenai pembuatan basis data CDF atau parameter-parameter distribusi. Pada sub bab ini akan dibahas mengenai contoh-contoh basis data CDF dan bagaimana menggunakan basis data ini untuk data peramalan. Contoh hanya diberikan untuk indek kekeringan SPI karena prinsip yang digunakan adalah sama baik SPI maupun SPEI.

Gambar 2 Skema pembagian algoritma untuk sistem peringatan dini kekeringan 
* Preview File Edit View Go Tools Window Help

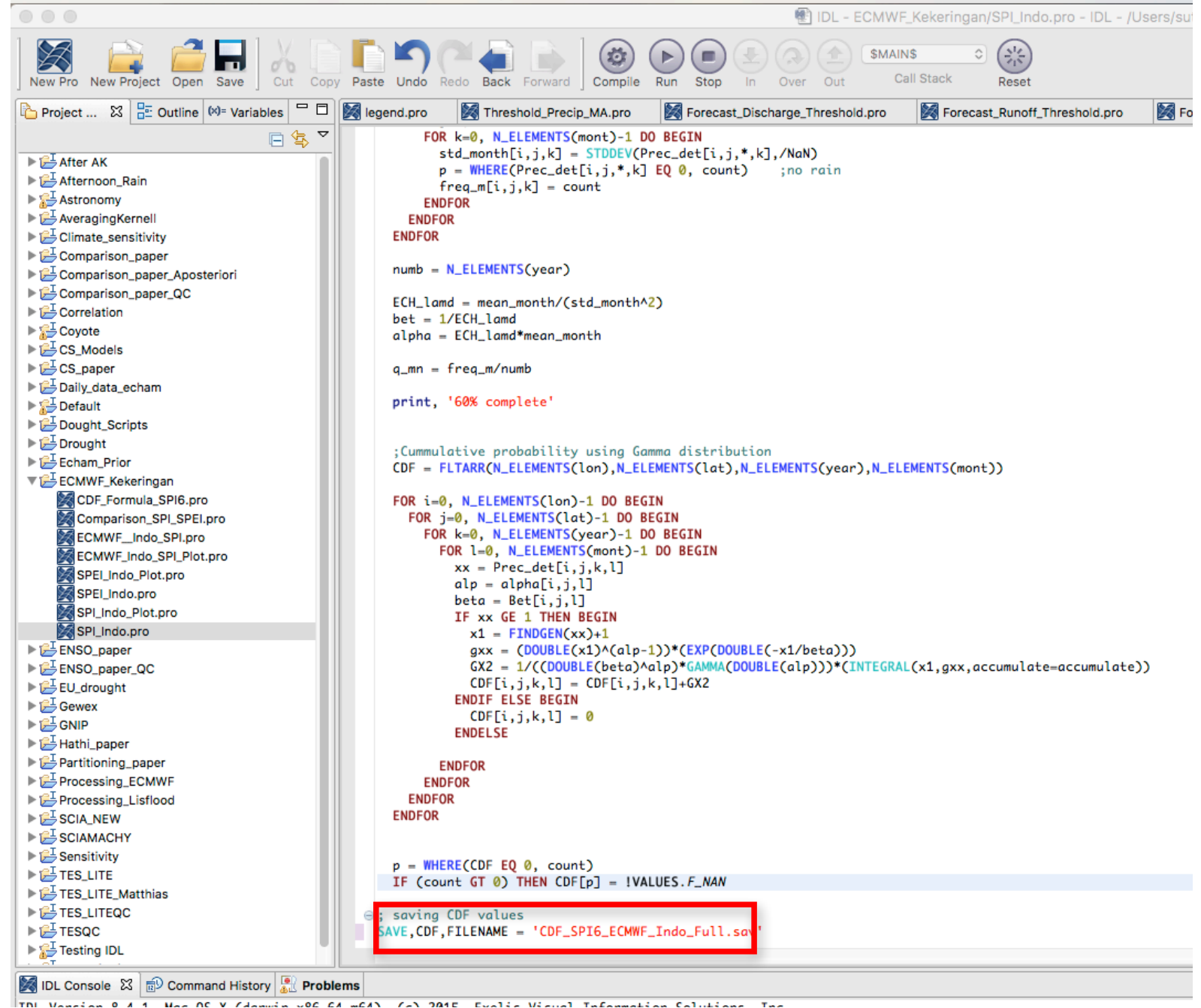

Gambar 3 Tampilan algoritma untuk perhitungan nilai CDF dengan menggunakan IDL

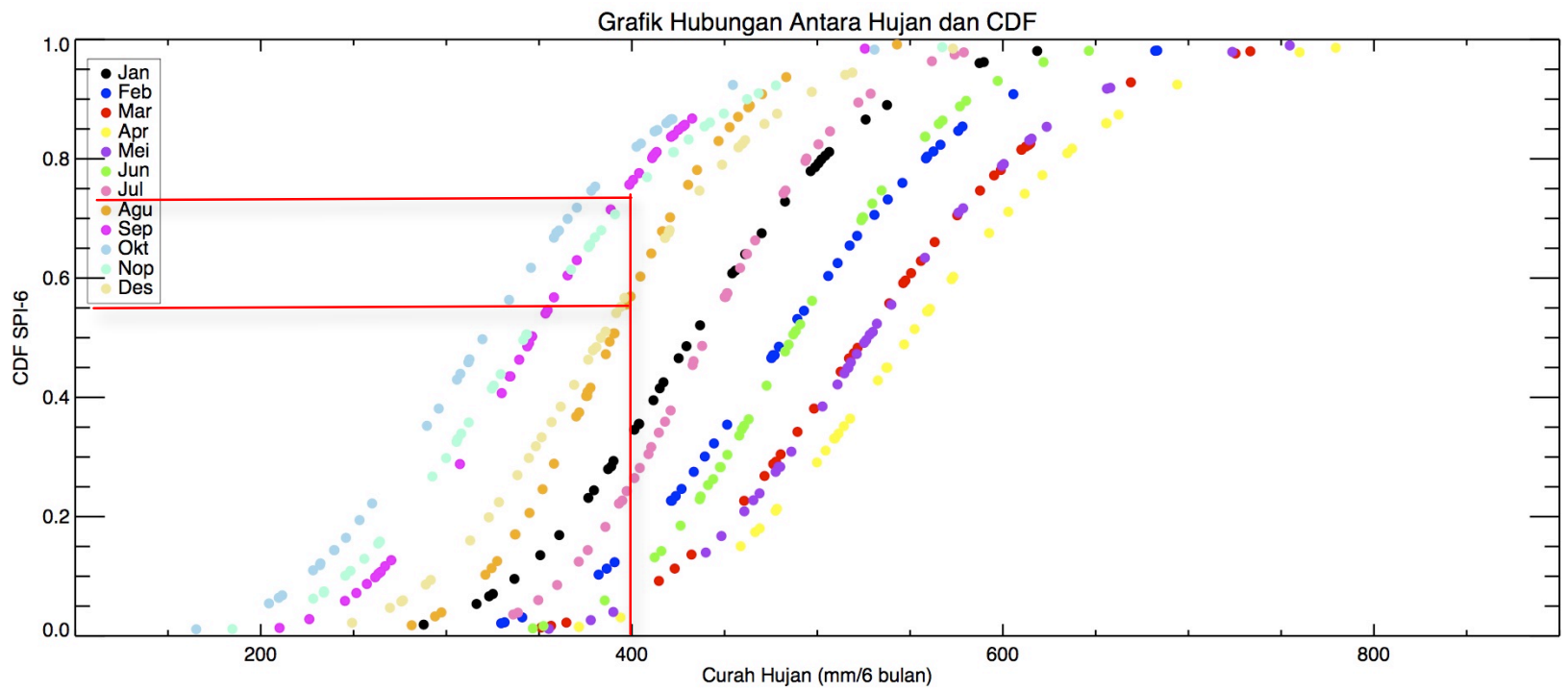

Gambar 4 Grafik hubungan antara curah hujan 6 bulan dengan CDF SPI- 6 untuk satu grid sel 
Gambar 4 menampilkan contoh basis data CDF yang telah dibuat setiap bulannya untuk satu grid sel. Pada Gambar 4 ini terlihat adanya hubungan positif antara curah hujan dan nilai CDFnya. Semakin besar curah hujan yang terjadi, maka nilai CDF juga akan semakin besar. Data tersebut merupakan data curah hujan total selama 6 bulan karena contoh dalam makalah ini menggunakan indek SPI-6 dan SPEI-6. Untuk nilai indek kekeringan lainnya, pada prinsipnya mempunyai hasil yang serupa hanya nilai curah hujan yang berbeda karena penjumlahan curah hujan tersebut.

Dengan adanya Gambar 4 tersebut, maka nilai hujan hasil peramalan yang diperoleh perlu dijumlahkan dengan data hujan sebelumnya selama 5 bulan untuk SPI- 6 ( 5 bulan data observasi dan 1 bulan data peramalan), dan kemudian dikonversi menjadi nilai CDF. Misal total hujan bulan Juli sampai Desember (6 bulan) adalah sebesar $400 \mathrm{~mm}$, maka nilai CDF yang diperoleh untuk bulan Desember adalah sebesar 0,58. Namun jika curah hujan yang sama terjadi untuk bulan April hingga September (6 bulan), maka nilai CDF bulan September adalah sebesar 0,76.

Contoh pada Gambar 4 lebih mudah dilakukan secara visual dan secara satu persatu, namun hasil yang didapat menjadi kurang akurat dan akan menemui kesulitan jika dilakukan dalam perhitungan. Grafik hubungan antara curah hujan dan CDF tidaklah linear atau tidak bisa dibuat garis persamaannya. Untuk mengatasi hal tersebut, maka nilai CDF yang diperoleh harus dirubah menjadi nilai log CDF (Gambar 5). Dengan diubahnya nilai CDF yang dihasilkan menjadi Log CDF, maka hubungan antara curah hujan dan Log CDF menjadi hubungan polinomial yang bisa dibuat rumus persamaannya.

Pada Gambar 5 terlihat bahwa hubungan antara curah hujan 6 bulanan dengan Log CDF mempunyai hubungan polinomial. Persamaan antara curah hujan dan Log CDF dapat dihitung dengan menggunakan hubungan polinomial tersebut dan menghasilkan formula 26 dengan nilai kesalahan sigma sebesar 0,0027 pada contoh Gambar 5.

$C D F=-49,13+(0,247 x C H)-\left(0,0003 x C H^{2}\right)-(2,658 \times 10$ -

$\left.{ }^{7} \mathrm{x} C H^{3}\right)+\left(8,673 \times 10^{-10} \times C H^{4}\right)-\left(5,019 \times 10^{-13} \times C^{5}\right)$

Dengan adanya formula 26 tersebut, maka berapapun nilai curah hujan yang dihasilkan dari data peramalan akan dengan mudah dikonversi ke dalam nilai CDF-nya. Gambar 5 juga menunjukkan contoh jika terdapat data cujan peramalan pada bulan Juli ditambahkan dengan data hujan 5 bulan sebelumnya dengan nilai total sebesar 583,7 mm, maka akan dihasilkan nilai Log CDF sebesar -0,443.

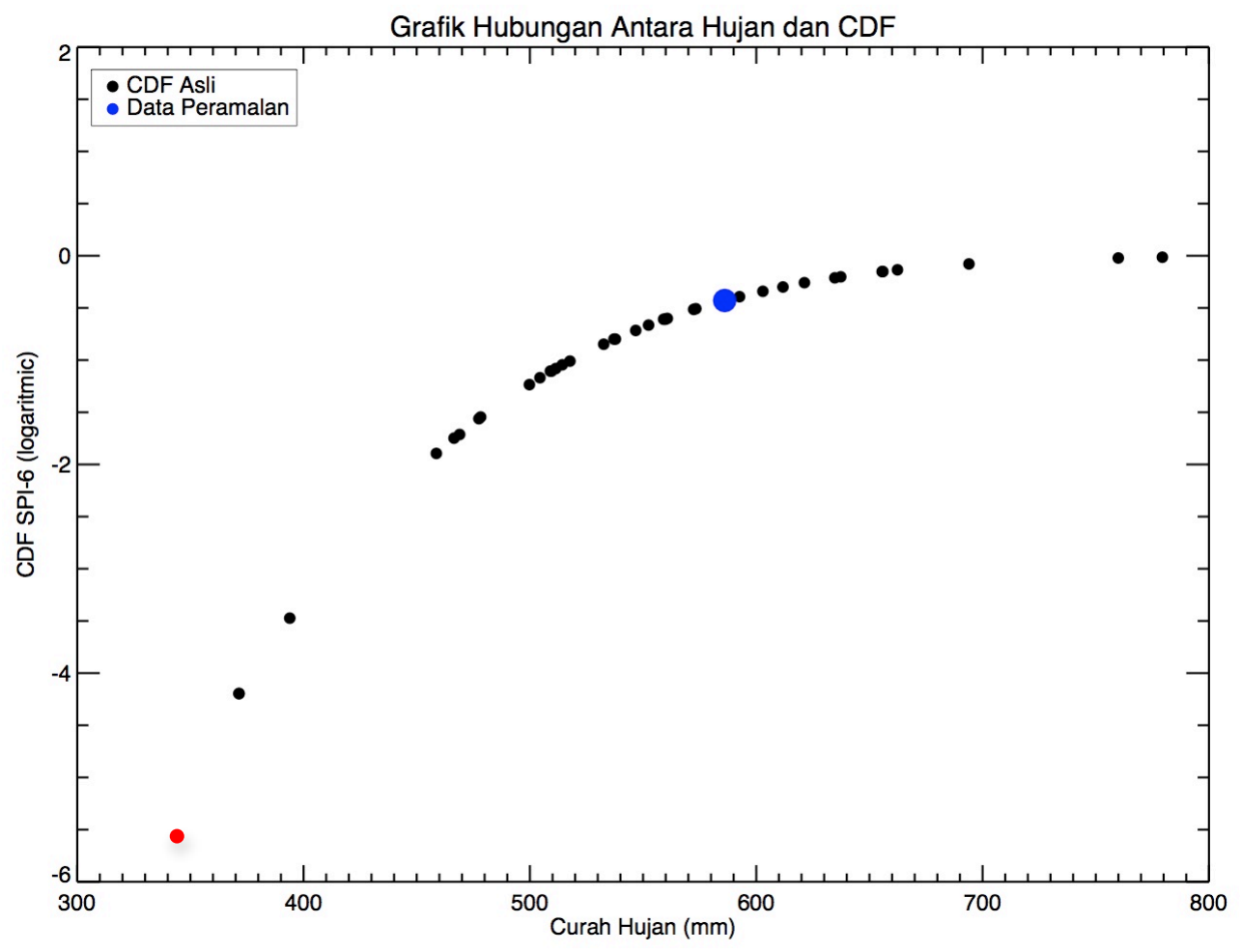

Gambar 5 Hubungan antara curah hujan dan Log CDF pada bulan Juli di satu grid sel. Titik merah adalah contoh data dengan nilai ekstrim kering 
Contoh-contoh yang diberikan diatas adalah contoh jika menggunakan basis data CDF. Untuk basis data yang berupa parameter $\alpha$ dan $\beta$ pada prinsipnya sama. Nilai curah hujan peramalan beserta nilai $\alpha$ dan $\beta$ pada bulan yang diramalkan digunakan untuk menghitung nilai CDF (rumus 5). Pada metode ini, maka nilai $\mathrm{CDF}$ pada rumus 5 akan dihitung kembali. Hal ini akan memberikan hasil perhitungan yang lebih lama daripada menggunakan CDF basis data, namun akan memberikan hasil yang lebih akurat. Kelemahan lain menggunakan CDF basis data adalah jika nilai hujan yang diramalkan adalah dibawah/diatas batas nilai minimum/maksimum hujan yang pernah terjadi (contoh titik merah pada Gambar 5). Jika demikian maka nilai CDF yang dihasilkan akan menjadi tidak akurat karena persamaan 26 tidak didesain untuk menghasilkan formula dengan data ekstrim tersebut.

\section{Contoh Tampilan Analisis Kekeringan di Indonesia}

Pada sub bab ini akan dibahas hasil analisis kekeringan di Indonesia dan akan digunakan sebagai contoh tampilan yang akan dihasilkan oleh sistem peringatan dini kekeringan ini. Secara garis besar hasil yang diperoleh dari analisis peramalan kekeringan di Indonesia berupa peta wilayah terdampak, dan data menerus kekeringan selama 7 bulan kedepan untuk setiap provinsi di Indonesia. Peta yang dihasilkan harus memuat wilayah mana saja yang akan mengalami kekeringan ringan, sedang, parah, dan ekstrim. Kekeringan ringan adalah kekeringan yang terjadi dengan nilai indek antara 0 hingga -1 , kekeringan sedang memiliki nilai indek kekeringan antara -1 hingga -1,5, kekeringan parah memiliki nilai indek -1,5 hingga 2, dan kekeringan ekstrim jika nilai indek kekeringan lebih dari -2 . Contoh peta kekeringan di Indonesia selama 6 bulan pada tahun 2015 dapat dilihat pada Gambar 6 .

Tampilan hasil analisis kekeringan secara spasial pada Gambar 6 dapat menunjukkan dengan lebih detail area mana saja yang terdampak kekeringan pada tahun 2015. Jika digunakan data peramalan, maka hasil yang akan ditampilkan akan sangat berguna untuk menampilkan daerah atau wilayah di Indonesia yang akan terdampak kekeringan selama 7 bulan ke depan beserta tingkat kekeringannya. Sebagai ilustrasi pada Gambar 6 terlihat bahwa kekeringan yang terjadi bertambah parah sejak bulan Agustus hingga bulan November 2015. Pada bulan Agustus, kekeringan ringan melanda hampir seluruh wilayah Indonesia dari Barat hingga Timur. Hanya Sumatera Utara dan Borneo bagian Utara yang tidak terdampak kekeringan. Sementara itu, wilayah selatan Borneo, sebagian Papua, sebagian kecil Sulawesi, dan NTT, mengalami kekeringan sedang.

Kekeringan yang terjadi bertambah luas dengan tingkat kekeringan yang membesar mulai bulan Oktober hingga Desember. Wilayah yang tadinya hanya mengalami kekeringan sedang, pada bulan Desember menjadi parah dan ekstrim. NTB, NTT, Selatan Borneo, Maluku barat, dan sebagian Sulawesi mengalami kekeringan ekstrim pada bulan Desember. Hampir seluruh pulau Sumatera mengalami kekeringan dengan tingkat ringan hingga parah, seluruh pulau Jawa mengalami kekeringan sedang hingga parah, sebagian besar pulau Kalimantan mengalami kekeringan ringan hingga parah, seluruh pulau Sulawesi mengalami kekeringan dengan tingkat ringan hingga parah, dan seluruh pulau Papua mengalami tingkat kekeringan dari ringan hingga ekstrim.

Tingkat kekeringan yang dihasilkan dengan metode SPI memberikan hasil yang lebih tinggi dibandingkan dengan metode SPEI. Hal ini mungkin dikarenakan pengaruh dari faktor suhu udara. Metode SPEI menggunakan analisis hasil dari perbedaan antara hujan dengan potensi penguapan. Sementara itu di wilayah Indonesia perbedaan suhu udara setiap bulannya tidak terlalu besar fluktuasinya dibanding dengan wilayah lain seperti Eropa dan Amerika yang memiliki 4 musim. Di Eropa, hasil dari SPEI dapat lebih tinggi dan lebih rendah cukup signifikan dibanding dengan SPI karena pengaruh dari suhu udara (Sutanto dan Adidarma, 2015). Meskipun hasil analisis tingkat kekeringan antara SPI dan SPEI di Indonesia berbeda, namun perbedaan itu tidak signifikan dan kedua metode memberikan indikasi kekeringan yang sama pada setiap wilayah hanya tingkat kekeringannya yang sedikit berbeda. Hasil perbandingan analisis kekeringan dengan metode SPI dan SPEI di wilayah Semarang dapat dilihat pada Gambar 7. 

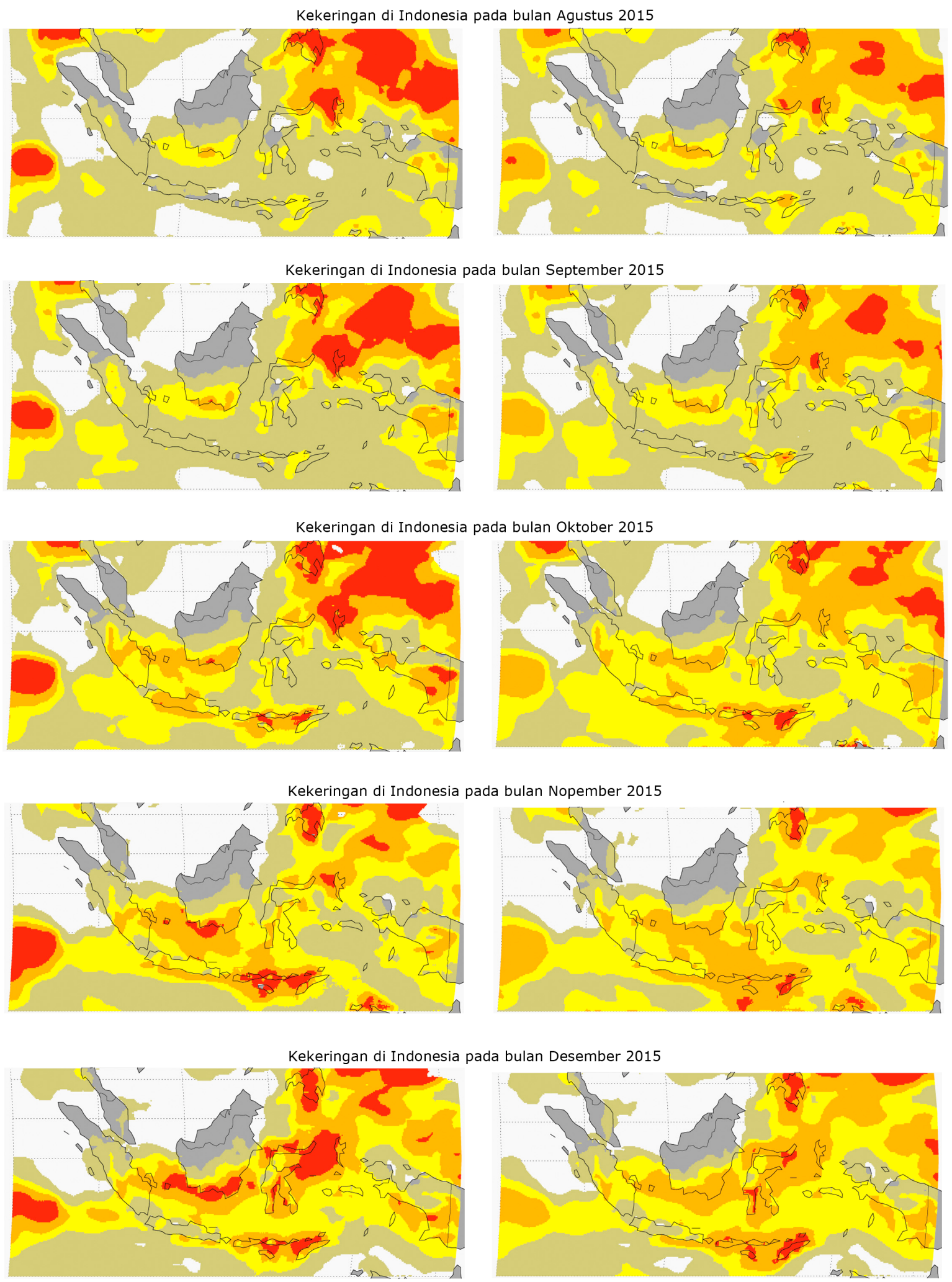

Kering Ringan

Kering Sedang

Kering Parah

Ekstrim Kering

Gambar 6 Kekeringan yang terjadi di Indonesia pada bulan Agustus hingga Desember 2015. Kolom kiri untuk hasil SPI-6 dan kolom kanan untuk hasil SPEI-6. 


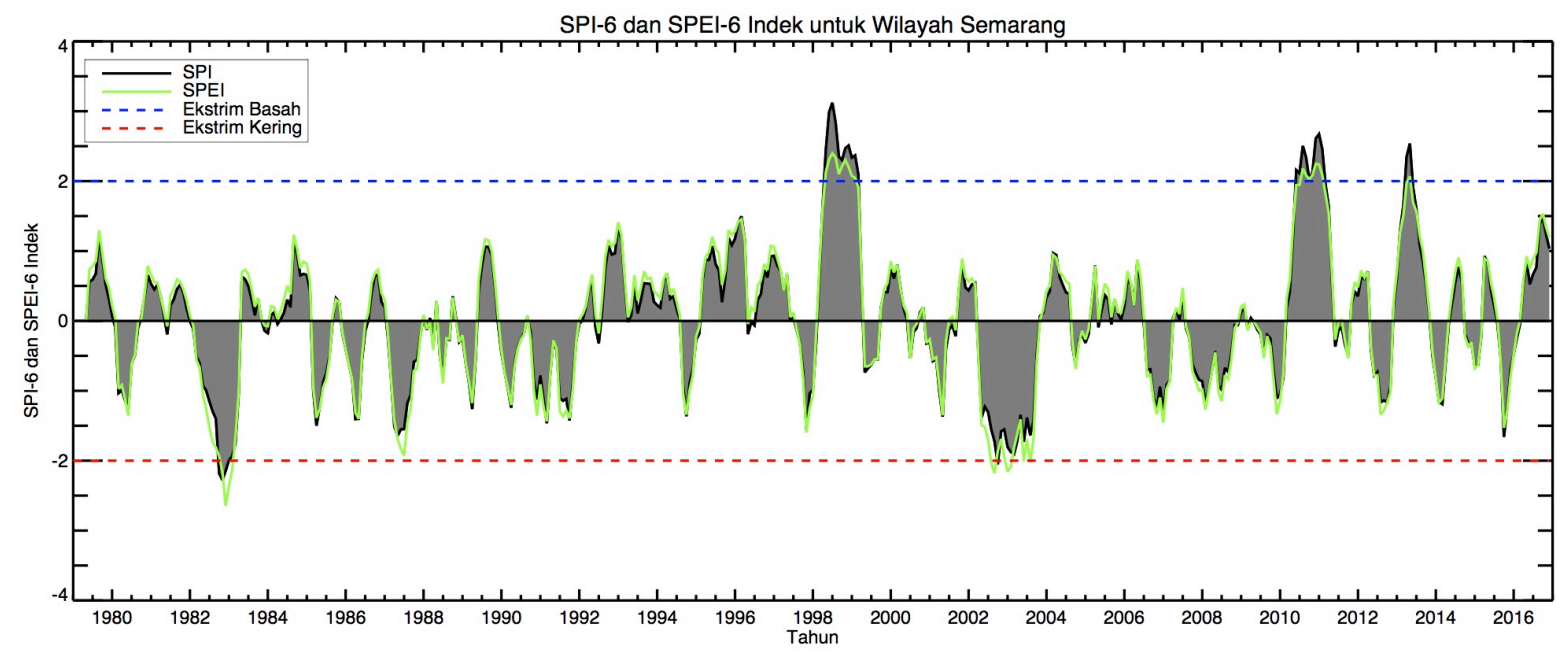

Gambar 7 Hasil analisis kekeringan di wilayah Semarang dengan metode SPI-6 dan SPEI-6

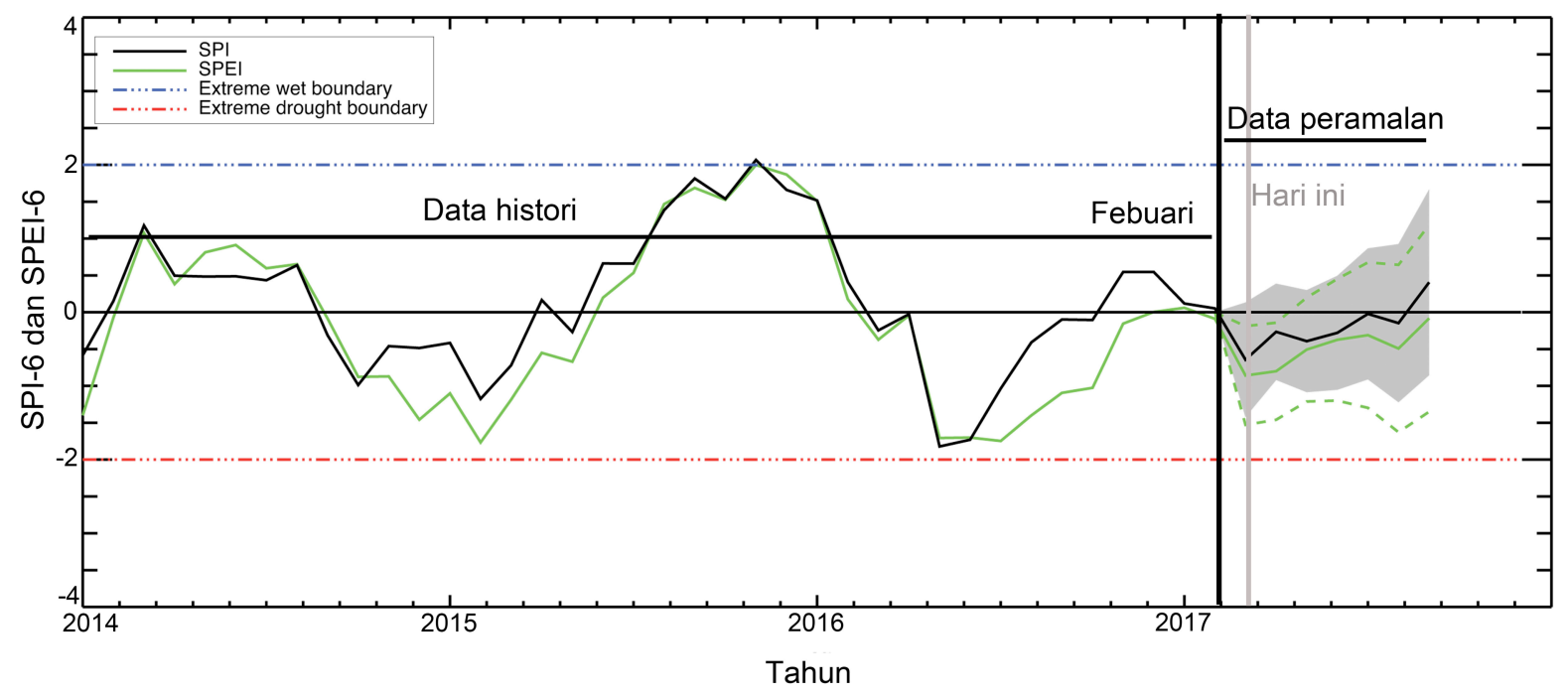

Gambar 8 Contoh tampilan hasil peramalan kekeringan dengan beberapa hasil pemodelan

Dari hasil perbandingan dengan kedua metode tersebut, maka dapat dilihat bahwa pada tahuntahun tertentu hasil dari SPEI menunjukkan nilai indek kekeringan yang lebih rendah dibandingkan dengan SPI, namun pada tahun lainnya hasil dari SPEI lebih tinggi dari SPI. Meskipun kedua metode memberikan hasil yang berbeda, perbedaan yang terjadi tidaklah signifikan. Selisih perbedaan hasil dari metode SPI dan SPEI sangatlah kecil.

\section{Contoh Hasil Peramalan Kekeringan}

Pada Gambar 7 diatas ditampilkan hasil analisis SPI dan SPEI di Semarang dengan menggunakan basis data histori dari ECMWF ERA Interim. Untuk hasil peramalan, curah hujan dan suhu udara yang dihasilkan berupa hasil keluaran dari beberapa model yang digunakan untuk meramalkan kondisi klimatologi (essemble models). Oleh karena itu grafik analisis yang dihasilkan oleh sistem peringatan dini ini haruslah memberikan nilai batas atas, batas bawah, dan nilai rata-rata atau tengah dari kumpulan model peramalan tersebut, sehingga para pembuat kebijakan dapat melihat secara detil tingkat kekeringan yang mungkin terjadi.

Gambar 8 menampilkan contoh hasil analisis kekeringan dengan menggunakan data peramalan ECMWF, yang diaplikasikan pada basis data kekeringan (algoritma bagian dua). Pada Gambar tersebut terlihat batas antara data histori dan data peramalan yang berupa garis warna abu-abu pada saat grafik tersebut di tampilkan. Bulan pada saat 
grafik tersebut ditampilkan sudah termasuk ke dalam data peramalan. Hal ini disebabkan karena adanya tenggang waktu untuk memproses data histori terlebih dahulu sebelum data histori ECMWF tersebut dapat ditampilkan. Hasil dari model-model peramalan ditampilkan dengan menunjukkan batas atas dan batas bawah model (warna abu-abu untuk SPI dan hijau untuk SPEI).

Dengan ditampilkannya nilai batas atas dan batas bawah hasil dari peramalan, maka kita bisa melihat bahwa tidak semua model meramalkan bahwa beberapa bulan ke depan akan terjadi kekeringan di wilayah tersebut. Sebagai contoh pada bulan disaat grafik tersebut dibuat (garis warna abu-abu), batas atas SPI menunjukkan bahwa bulan tersebut termasuk bulan yang basah (nilai SPI diatas nol) sementara batas bawah menunjukkan pada bulan tersebut akan terjadi kekeringan dengan nilai SPI $-1,5$ (kekeringan parah). Lain halnya dengan SPEI, hasil peramalan SPEI menunjukkan bahwa bulan tersebut terjadi kekeringan (batas atas dan bawah dibawah nol). Dengan adanya perbedaan hasil peramalan tersebut, maka para pembuat kebijakan dapat dengan bijak menentukan langkah-langkah yang akan diambil.

\section{Koreksi Bias CDF Peramalan}

Data peramalan yang digunakan mempunyai karakteristik yang berbeda dengan data pengamatan. Hal ini dikarenakan data peramalan merupakan hasil dari pemodelan, sedangkan data pengamatan merupakan data hasil dari analisis ulang (re-analysis) dengan menggabungkan data pengamatan baik dari radar, satelit, maupun pengamatan lapangan. Untuk dapat memberikan hasil peramalan yang akurat dengan menggunakan data histori, maka perlu dilakukan koreksi data peramalan tersebut terhadap bias yang terjadi (Dee dan Silva, 1998). Koreksi ini dapat dilakukan pada nilai CDF untuk setiap bulannya untuk setiap grid sel. Contoh nilai CDF data histori dan peramalan dapat dilihat pada gambar 9 .

Pada Gambar 9 terlihat bahwa CDF data histori dan peramalan mempunyai nilai yang berbeda satu dengan yang lainnya. Sebagai contoh jika hujan diramalkan akan turun dengan nilai total sebesar $500 \mathrm{~mm}$ pada bulan Januari, maka akan dihasilkan nilai CDF sebesar 0,58. Sedangkan jika kita menggunakan grafik historis, maka nilai CDF yang dihasilkan adalah sebesar 0,78. Dengan adanya perbedaan nilai CDF yang cukup signifikan ini, maka hasil dari peramalan kekeringan akan menjadi tidak akurat. Oleh karena itu koreksi bias pada data peramalan terhadap data histori harus dilakukan (panah pada Gambar 9).

Nilai CDF data peramalan (warna biru pada Gambar 9) didapatkan dengan menggunakan data peramalan pada tahun-tahun sebelumnya atau disebut data peramalan histori (Hindcast). Hal ini yang menyusahkan peneliti untuk melakukan koreksi bias karena banyaknya data yang harus di proses baik data histori maupun hindcast yang memerlukan panjang data minimal 30 tahun. Pembahasan mengenai koreksi bias secara detil tidak dibahas dalam makalah ini, namun pembahasan ini memberikan gambaran kepada peneliti akan arti pentingnya koreksi bias pada data peramalan jika akan digunakan bersamaan dengan data histori.

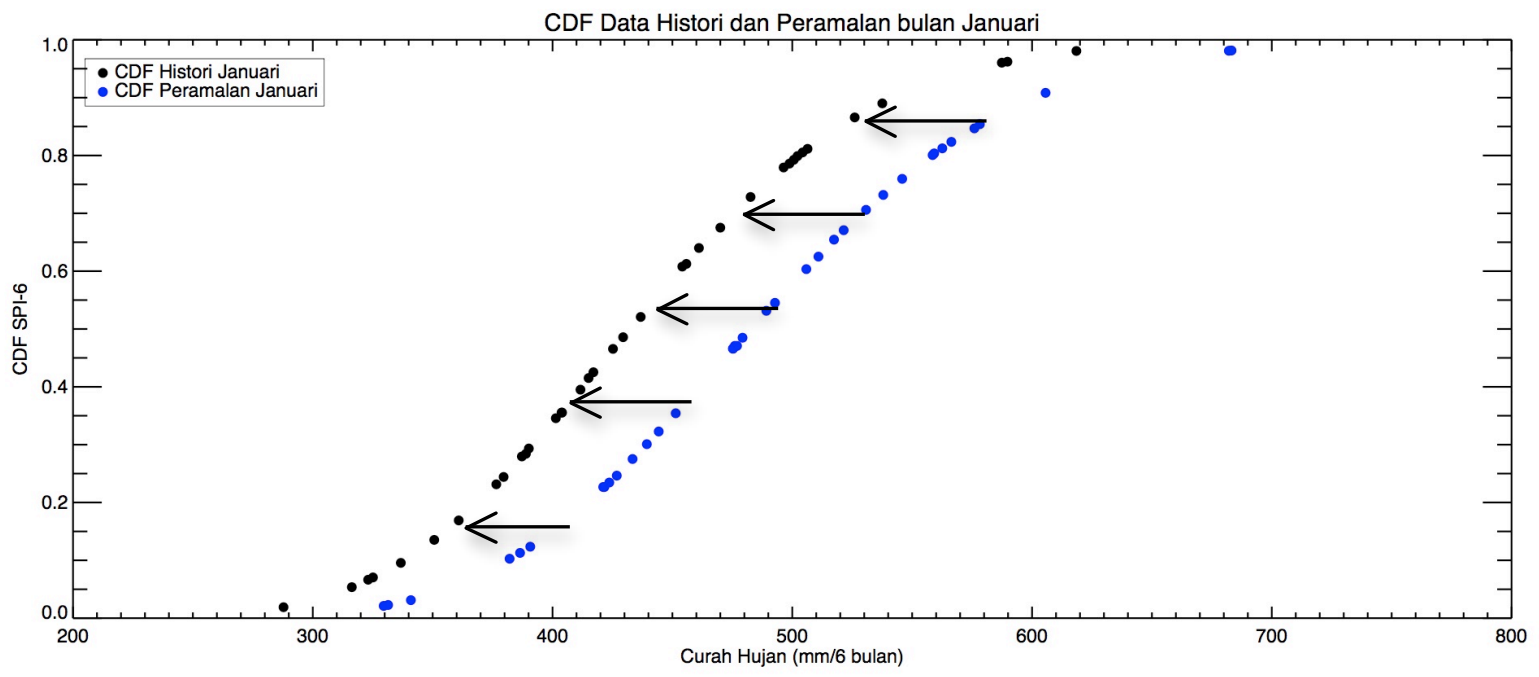

Gambar 9 CDF bulan Januari untuk data histori dan peramalan 


\section{KESIMPULAN DAN SARAN}

Dalam makalah ini telah dibahas secara detil mengenai wawasan dan konsep pengembangan sistem peringatan dini kekeringan yang dapat diaplikasikan di Indonesia. Konsep ini disajikan dengan menggunakan metode-metode analisis kekeringan yang lazim digunakan di Indonesia, seperti SPI dan SPEI, dan dengan menggunakan sistem yang sudah berjalan untuk peringatan dini banjir (FEWS program dan data peramalan ECMWF-BMKG).

Untuk mempercepat analisis kekeringan di seluruh wilayah Indonesia dengan jumlah grid sel sebanyak 417x169 (longitude x latitude), maka diusulkan untuk membagi analisis menjadi dua algoritma. Algoritma pertama adalah untuk membuat basis data nilai parameter distribusi, dan algoritma kedua adalah untuk menghitung nilai SPI dan SPEI dengan data peramalan. Hasil yang harus ditampilkan dari peramalan kekeringan ini adalah peta kekeringan di Indonesia setiap bulannya, hingga 7 bulan ke depan, dan grafik indeks kekeringan untuk setiap provinsi di Indonesia. Grafik indeks peramalan kekeringan ini harus menyertakan nilai batas atas dan batas bawah dari hasil seluruh pemodelan peramalan (essembled forecast).

Untuk dapat memberikan hasil peramalan kekeringan yang cukup akurat, maka sangat disarankan untuk dilakukan koreksi bias pada data peramalan. Hal ini sangat penting karena adanya perbedaan karakteristik antara pengamatan dan hasil pemodelan. Untuk mengkoreksi nilai CDF ini, maka diperlukan data peramalan masa lalu yang cukup panjang (hindcast), dimana data tersebut sangat susah didapatkan. Koreksi data peramalan yang dibahas pada makalah ini dilakukan pada nilai CDF, namun bagaimana cara mengkoreksi parameter distribusi $(\alpha, \beta, \gamma)$ peramalan masih belum pernah dikaji lebih lanjut.

Dengan adanya pembahasan mengenai wawasan sistem peringatan dini kekeringan pada makalah ini, maka diharapkan peneliti dapat mempunyai gambaran mengenai pembuatan sistem peringatan dini kekeringan untuk wilayah Indonesia. Semoga kedepannya peringatan dini kekeringan ini dapat di implementasikan menjadi suatu sistem peringatan dini yang akurat dan terpercaya untuk Indonesia.

\section{DAFTAR PUSTAKA}

Alley W. M. 1984. The Palmer drought severity index: Limitations and applications, J. Appl. Meteor., 23, 1100-1109.

Betts, A. K., dan Jakob, C. 2002, Evaluation of the diurnal cycle of precipitation, surface thermodynamics, and surface fluxes in the ECMWF model using LBA data, J. Geophys. Res, 107, D20, 8045, doi:10.1029/2001JD000427.

Bloomfield J. P., dan Marchant B. P. 2013. Analysis of groundwater drought building on the standardized precipitation index approach, Hydrol. Earth Syst. Sci., 17, 4769-4787, doi:10.5194/hess-17-4769-2013.

CNN Indonesia. 2015. Kekeringan landa delapan provinsi di Indonesia, Selasa 28 July 2015, diperolehdari http://www.cnnindonesia.com/nasional/2 0150728095930-20-68525/kekeringanlanda-delapan-provinsi-diindonesia/,Diakses pada tanggal 9 February 2017.

Dai A. 2010. Drought under global warming: a review, WIREs Clim. Change, 2, 45-65, doi:10.1002/wcc.81.

Dee D. P., dan Da Silva A. M. 1998. Data assimilation in the presence of forecast bias, Q. J. R. Meteorol. Soc, 124, 269-295.

Dee D. P., Uppala S. M., Simmons A. J., Berrisford P., Poli P., dan rekan-rekan. 2011. The ERAinterim reanalysis: configuration and performance of the data assimilation system, Q. J. R. Meteorol. Soc., 137, 553597.

Djaman K., Balde A. B., Sow A., Muller B., Irmak S., N'Diaye M. K., Manneh B., Moukoumbi Y. D., Futakuchi K., dan Saito K. 2015. Evaluation of sixteen reference evapotranspiration methods under sahelian conditions in the Senegal River Valley, J. Hydrol.: Regional Studies, 3, 139159, doi:10.1016/j.ejrh.2015.02.002.

EurAqua. 2004. Discussion Document: Towards a European Drought Policy.

Federal Emergency Management Agency (FEMA). 1995. National Mitigation Strategy: Partnerships for building safer communities. Mitigation Directorate, p.2, Washington, DC: Federal Emergency Management Agency, 40. 
Hamill T. M., Hagedorn R., dan Whitaker J. S. 2007. Probabilistic Forecast Calibration Using ECMWF and GFS Ensemble Reforecasts, part II: Precipitation, Mon. Wea. Rev., 136, 2620-2632, doi: 10.1175/2007MWR2411.1.

Hatmoko, W., Radhika, Raharja, B., Tollenaar, D., dan Vernimmen, R. 2015, Monitoring and prediction of hydrological drought using a drought early warning system in PemaliComal river basin, Indonesia, Procedia Environmental Sciences, 24, 56-64, doi:10.1016/j.proenv.2015.03.009.

Hisdal H., Tallaksen L. M., Clausen B., Peters E., dan Gustard A. 2004. Hydrological drought characteristics, in: Hydrological Drought. Processes and Estimation Methods for Streamflow and Groundwater, edited by: Tallaksen, L. M. and Van Lanen, H., Developments in Water Science 48, Elsevier Science B.V, 139-198.

Hosking J. R. M. 1990. L-Moments: analysis and estimation of distributions using linear combinations of order statistics, J. Royal Statistical Soc. Series B (Methodological), Vol. 52, 105-124.

Jun-Ichi H., Yamanaka M. D., Matsumoto J., Fukao S., Winarso P. A., dan Sribimawati T. 2002. Spatial and temporal variations of the rainy season over Indonesia and their link to ENSO, Journal of the Meteorological Society of Japan, Vol. 80 , No. 2, pp. 285310.

Kallis G. 2008. Droughts, Annu. Rev. Env. Resour., 33:85-118.

McKee T. B., Doesken N. J., dan Kleist J. 1993. The relationship of drought frequency and duration to time scales, Preprints, Eighth Conf. on Applied Climatology. Anaheim, CA, Amer.Meteor. Soc., 179-184.

Palmer W. C. 1965. Meteorological droughts. U.S. Department of Commerce, Weather Bureau Research Paper 45, 58 pp.

Persson A. 2001. User guide to ECMWF forecast products, Meteorological Bulletin, M3.2, ECMWF, 2001.

Robine J-M., Cheung S.L.K., Le Roy S., van Oyen H., Griffiths C., Michel J-P., dan Herrmann F.R. 2008. Death toll exceeded 70,000 in Europe during the summer of 2003, Comp. Rendus Biol., 331:171-178, doi:10.1016/j.crvi.2007.12.001.
Schumacher, C., dan Houze JR, R. A. 2003, Stratiform rain in the tropics as seen by the TRMM precipitation radar, J. Clim., 1739-1756.

Shukla S., dan Wood W. 2008. Use of standardized runoff index for characterizing hydrologic drought, Geophys. Res. Lett., 35, L02405, doi:10.1029/2007GL032487.

Sutanto S. J., dan Adidarma W. K. 2015. Analisis kekeringan di beberapa negara Eropa dengan menggunakan data dari model iklim global dan di Indonesia menggunakan data hujan, Jurnal Sumber Daya Air, Vol. 11, No. 1, 1-6.

Sutanto S. J., Hoffmann G., Adidarma W., dan Röckmann T. 2013. Correlation of drought related to ENSO and water isotopes in Indonesia, $4^{\text {th }}$ International Seminar of HATHI, 6-8 September 2013, Yogyakarta.

Taufik M., Torfs P. J. J. F., Uilenhoet R., Jones P. D., Murdiyarso D., dan Van Lanen H. A. J. 2017. Amplification of wildfire area burnt by hydrological drought in the humid tropics, Nature Climate Change, doi:10.1038/NCLIMATE3280.

Van Loon A. F. 2015. Hydrological drought explained, WIREs Water, doi:10.1002/wat2.1085.

Van Loon A. F., dan van Lanen H. A. J. 2012. A process-based typology of hydrological drought, Hydrol. Earth Syst. Sci., 16, 19151946, doi:10.5194/hess-16-1915-2012.

Vicente-Serrano S. M., Begueria S., dan LopezMoreno J. I. 2010. A multiscalar drought index sensitive to global warming: The Standardized Precipitation Evapotranspiration Index, Journal of climate., Vol. 23, pages 1696-1718, doi: 10.1175/2009JCLI2909.1.

Wells N., Goddard S., dan Hayes M. J. 2004. A selfcalibrating Palmer Drought Severity Index, American Meteorological Society, 23352351.

Wu, H., Hayes, M. J., Wilhite, D. A., dan Svoboda, M. D. 2005, The effect of the length of record on the standardized precipitation index calculation, Int. J. Climatol., 25, pages 505520, doi:10.1002/joc.1142.

Yevjevich V. 1967.An objective approach to definition and investigations of continental hydrologic droughts, Colorado State University. 


\section{UCAPAN TERIMA KASIH}

Pada kesempatan ini penulis mengucapkan terima kasih kepada Henny van Lanen atas kesempatan yang diberikan untuk mempelajari dan berdiskusi tentang sistem peringatan dini kekeringan. Tidak lupa penulis mengucapkan terima kasih kepada para reviewer atas masukannya demi terciptanya makalah yang lebih baik. 